\title{
EFFICIENCY OF THE STORED LOCUST AND GRASSHOPPER INSECTICIDES IN EGYPT ON CATANTOPS AXILLARIS THUNBERG (ORTHOPTERA: ACRIDIDAE) UNDER THE FIELD CONDITIONS OF BAHARIA OASIS
}

\author{
EL-GAMMAL, A. M. ${ }^{1}$, M.T. MOHAMED ${ }^{1}$, GEHAN A. MOHAMED ${ }^{1}$, \\ M. A. HINDY ${ }^{2}$ AND M. A. IBRAHIM ${ }^{1}$.
}

\section{Locust and Grasshoppers Research Department \\ 2. Spray Technology Research Department}

Plant Protection Res. Institute, ARC, Dokki, Giza

(Manuscript received $1^{\text {st }}$. December 2008)

\begin{abstract}
The chemical insecticides still the most effective controlling agent against the heavy plagues of the desert locust, Schistocerca gregaria and the other locust species. The affected countries with these insects used to keep sufficient amounts of the recommended insecticides by food and Agriculture Organization (FAO) for many years in their stores to protect their Agricultural economy from damage by locust plagues. These stocks have to be re-evaluated annually to insure their efficiency against locust.

Therefore, the present study was carried out in Baharia Oasis to re-evaluate the efficieny of some insecticidies formulations against the most predomenent Acrididae member, the Grasshopper Catantops axillaris in August, 2008. The tested insecticides were, ultra low volume (ULV) formulations of the organophosphorous chlorpyrifos $45 \%$ (Bestban and Briban), pyritheroide Deltamethrin $1.25 \%$ emulsifable concentrate (EC) formulation of the organophosphate Malathion 57\% (Malatox) and, ULV formulation, Green Muscles, of the fungus, Metarhizium flavoviride. The recommended doses of FAO $8^{\underline{t}}$ meeting of pesticide Referee group, 1999 were used. The samples of the tested insecticides were obtained from the insecticides store of the General Directorate for locust and grasshoppers control in Baharia Oasis. Green Muscles oil formulation sample was a gift from FAO project in Locust and Grasshopper Research Department, Plant protection Res. Institute, Agriculture Res. Center, Ministry of Agric., Egypt.
\end{abstract}

The obtained results indicated that, Deltamethrin and Bestiban insecticides were the most effective ones against $C$. axillaris, followed by a moderate effect of Briban. The EC Malatox exihibited high efficiency only during the first 3 days of the application. The micoinsecticide Green Muscles lasted 7 days to induce its lethal effect, reaching its maximum effect after 9 days.

Thus, it could be concluded that, the oil ULV insecticides have to be used only against locust in the desert and non-edible crops areas, but EC organophosphorous insecticides are preferred to use against locusts and Grasshoppers on the edible crops and cultivated area. Green Muscles could be used against the low density populations of the immature stages of these insects without treating non-target arthropods other than orthopterans. The ULV 
formulation stock of Chlopyrifos $45 \%$, Briban have to be renewed. Moreover, the present field study drew the attention to reevaluating the ground sprayers periodically as well as the stored Locust and Grasshoppers insecticides.

\section{INTRODUCTION}

Compeating Locusts and Grasshoppers in the affected countries still rely on the chemical insecticides, because studies on alternative controlling agents still under controlled conditions in the laboratory, beside some field trials to evaluate the efficiency of some formulations of the fungus Metarhizium spp. under field conditions, Peveling et al. (1999) carried out medium-scale experimental field trials in Niger using the mycoinsecticide $M$. anisopliae compared with the organophosphate Fenitrothion insecticide against Qedoleus senegalensis. Both controlling agents were effective, the efficiency of $M$. anisopliae and Fenitrothion were $86 \%$ and $76 \%$, respectively. They concluded that, the micoinsecticide can be effective as Fenitrothion without threating non-target arthropods other than Orthopterous. In another field trials in Niger, Langewald et al. (1999) found that, the oil formulation of $M$. anisopliae significantly reduced the population of this Grasshopper by $90 \%$ after 7 days, whereas Fentrothion achieved more than $90 \%$ reduction shortely after application, but due to the immigration, the Grasshopper population recovered to the initial level within 16 days. Recently, laboratory and field studies were conducted to evaluate some alternatives from different chemical and biochemical classes against locust and Grasshoppers such as insect growth regulators, anti-moulting, anti-feedaints and Metarhizium spp. (El-Gammal et al., 2002, 2004 (a , b) , El-Gammal and Mohamed, (2008) and ElGawhary et al., (2006). They observed that, the naturally produced bio-insecticides by plants or by micro-organisms could provide effective ulternative controlling agents against Acrididae insects. It suppress producing the mobile swarms from their breeding sites if we have the means to discover these sites in the huge distributed area of desert locust which estimated by approx . 30 million square km. For this difficulty, the affected countries used to keep sufficient amounts of insecticides in their stores for many years to compete the insuppressible Locust plagues effectively in suitable time.

To insure this goal, the present study was conducted to reevaluate some of the stored insecticides as well as the micoinsecticides Green Muscles against the available member of Acrididae, C. axillaris in Baharia Oasis, Egypt, to draw attension to any intangible deficiency in the toxicity of the stored controlling agents before any sudden plague of the desert locust, to Egypt. 


\section{MATERIALS AND METHODS}

\section{Target insects}

It was found that the Grasshopper, Catantopis axillaris is the most predoment species on alfalfa, Medicago sativa and Zea miaze in Baharia Oasis, followed by other species such as, the grasshopper, Chrotogonus homalodermus and Acrida turrita (Mohamed, 2007). So, C. axillaris was chosen to evaluate the toxicity of the stored insecticides stock in Baharia Base under the field conditions of this Oasis during August, 2008.

\section{The tested insecticides}

Samples of the stored insecticides stock for Locust and Grasshopper control in Baharia Oasis for one to three years were evaluated wthin its validity or re- analysized for chemical and physical properties at central laboratory of pesticide. These samples were two of ultra low volume (ULV) formulations of the organophosphate Chlorpyrifos 45\% (Bestiban and Briban), the pyritheroide ULV formulation, Deltamethrin $1.25 \%$ and the emulsifuable concenterate (EC) formulation of the organophosphate Malathion, (Malatox 57\%). These samples were obtained from the stored insecticides stock in Baharia Base, General Directorate for Locust and Grasshopper control, Ministry of Agriculture. The sample of the oil formulation of Metarhizium flavoviride was a gift from Food and Agriculture Organization (FAO) project in Locust and Grasshopper Research Department, it's trade name is Green Muscles. These chemicals and the micoinsecticide (Green Muscles) have been included by FAO Desert Locust guid appendix (Gressman and Dobson, 2001).

\section{Experimental field design}

Medium-scale experimental field applications of the tested Locust and Grasshopper insecticides were conducted in Baharia Oasis, August, 2008. These insecticides were ULV formulations of Chlorpyrifos, 45\% (Bestiban and Briban), the pyritheroied ULV formulation, Deltamethrin, $1.25 \%$, the E.C. formulation of Malathion, (Malatox 57\%), and the micoinsecticide, Green Muscles. The applications of these controlling agents were carried out in experimental plots of alfalfa and maize that were heavely infected with the latent nymphal instars of $C$. axillaris. Each application was replicate three times in experimental plots of about 300 square meter $\left(\mathrm{m}^{2}\right)$ with a wide belt of $200 \mathrm{~m}^{2}$ in between to prevent the transition of the Grasshopper from one plot to another and avoid drift spraying between treatments In addition untreated plot/treatment was precified as control (check) . 


\section{Field application}

The recommended doses rates of Locusts pesticides by the $8^{\text {th }}$ meeting of FAO pesticide Refree Group, (1999) were used in the present field study. These doses were, $225 \mathrm{gm}$.a.i/ha equal to $94.54 \mathrm{gm}$. a.i./fed for Chlorpyrifos ULV formulation, 12.5 gm.a.i./ha equal to $5.25 \mathrm{gm}$.a.i./fed.for Deltamethrin ULV formulation, $925 \mathrm{gm}$.a.i./ha equal to $388.66 \mathrm{gm} . a . \mathrm{i} / \mathrm{fed}$.for Malatox EC formulation and $100 \mathrm{gm} . \mathrm{a.i} / \mathrm{ha}$ equal to 42.02 gm.a.i./fed. for Green Muscles ULV formulation. The ULV formulations were applied by a hand-held spinning disc battery sprayer, provided with a pink restrictor. The doses of the chemical insecticides were diluted with diesel oil, whereas the dose of the oil formulation, Green Muslces was dissolved in Natural oil. the application rate was 1.89 liter/fed. with swath width of $10 \mathrm{~m}$. and a flow rate of $180 \mathrm{ml} / \mathrm{min}$. to cover each plot with $135.0 \mathrm{ml}$ including the application rate of the controlling agent. On the other hand, Malatox 57\% EC formulation was applied with application rate of 20 liter /feddan aqueous solution by , using motorized knapsake sprayer Solo with 5.0 meter swath width, and flow rate was $0.950 \mathrm{~L} / \mathrm{min}$.

\section{Sampling and evaluation}

The treated and untreated control plots were sampled daily for 10 days after application of the chemicals and mico-insecticides using sweep-net sampling technique. This technique was conducted in 5 sites in each plot, and repeated twice in each site, so each plot was sampled 10 times daily for 10 days after treatment. The numbers of the treated and untreated nymphs of the grasshopper, C. axillaris were related to 10 sweeps. The reduction percentages in the population density of the treated plots were calculatd daily by Henderson and Tilton equation (1955).

\section{RESULTS AND DISCUSSION}

\section{Efficacy of the ULV formulations of Chlorpyrifos $45 \%$}

The present study was conducted to reevaluate (Check up) the efficiency of some stored Locust and Grasshoppers control agents against the most predomenent member of Acrididae, C. axillaris in Baharia Oasis during August 2008.

Table (1) shows that, the application of the ULV formulations of the organophosphate Chlorpyrifos 45\% (Bestiban and Briban) against the Grasshopper $C$. axillaris on alfalfa obviously reduced the number of this insect. The reduction percentages after one day of application (initial kill) of Bestiban and Briban insecticides were 81.19 and 53.47, respectively. These percentages were increased after two days of application they were, 86.14 and 73.48 for each inseticide, respectively. The 
efficacy of Bestiban still high to day $5^{\text {th }}$ of treatment, in which its reduction percent was 74.26 compared to $65.44 \%$ of reduction after Briban application in the same day. The efficiency decline slightly of Bestiban application, the reduction percentages achieved the least $(66.68 \%)$ at the $10^{\text {th }}$ day. But in the same period from the $6^{\text {th }}$ day (71.6) of the efficacy of Bribane was sharply reduced, its reduction percentages during this period ranged between , 59.39, and 28.06, respectively.

It's clear that, the two formulations of Chlorpyrifos 45\% (Bestiban and Briban) still effective against $C$. axillaris, but the persistence of Bestiban was more than Briban which indicates that Bestiban didn't suffer from storage and its initial and latent kill still convenient to compete locust and grasshoppers for at least one year after which this re-evaluation have to be repeated.

Table 1. The first annual reevaluation of the stored ULV formulations of Chlorpyrifose 45\% (Bestiban and Briban) against the Grasshopper Catantopis axillaris on alfalfa in Baharia Oasis, August 2008.

\begin{tabular}{|c|c|c|c|c|c|c|}
\hline \multirow{2}{*}{$\begin{array}{l}\text { Days of } \\
\text { treatments }\end{array}$} & \multicolumn{2}{|c|}{$\begin{array}{l}\text { Average No. Control } \\
\text { insects/ } 10 \text { sweeps }\end{array}$} & \multicolumn{2}{|c|}{$\begin{array}{c}\text { Average No. treated } \\
\text { insects/ } 10 \text { sweeps }\end{array}$} & \multicolumn{2}{|c|}{$\begin{array}{c}\% \text { reduction caused } \\
\text { by }\end{array}$} \\
\hline & $\begin{array}{c}\text { In } \\
\text { Bestiban } \\
\text { plots }\end{array}$ & $\begin{array}{c}\text { In Briban } \\
\text { Plots. }\end{array}$ & $\begin{array}{c}\text { In } \\
\text { Bestiban } \\
\text { plots }\end{array}$ & $\begin{array}{l}\text { In } \\
\text { Briban } \\
\text { Plots. }\end{array}$ & Bestiban & Briban \\
\hline 0 & 38.00 & 70.00 & 42.00 & 48.00 & 0.00 & 0.00 \\
\hline 1 & 37.67 & 70.33 & 8.00 & 22.33 & 81.19 & 53.47 \\
\hline 2 & 38.33 & 68.33 & 6.00 & 12.67 & 86.14 & 73.48 \\
\hline 3 & 37.00 & 68.33 & 8.67 & 11.67 & 78.37 & 75.52 \\
\hline 4 & 38.67 & 67.67 & 10.33 & 12.33 & 75.50 & 73.22 \\
\hline 5 & 38.33 & 65.00 & 11.00 & 15.33 & 74.26 & 65.44 \\
\hline 6 & 36.00 & 65.33 & 11.33 & 18.33 & 71.65 & 59.39 \\
\hline 7 & 36.67 & 63.67 & 12.67 & 25.33 & 68.88 & 42.23 \\
\hline 8 & 36.33 & 66.33 & 12.33 & 34.33 & 69.55 & 24.40 \\
\hline 9 & 38.33 & 68.67 & 12.67 & 33.00 & 70.30 & 25.48 \\
\hline 10 & 38.67 & 64.33 & 14.33 & 31.67 & 66.68 & 28.06 \\
\hline
\end{tabular}

\section{Effects of the EC formulation of Malathion (Malatox 57\%)}

The application of the organophosphate Malathion (Malatox 57\%) against the field population of $C$. axillaris was conducted on Zea maize in Baharia Oasis in the same period of the previous experiments. This formulation was sprayed by the low volume spraying technique with a rate of application of 20 liter/ feddan using motorized knapsak sprayer Solo . 
Table 2. Suscebtibility of the Grasshopper, Catantopis axillaris to Malatox 57\%.

\begin{tabular}{|c|c|c|c|}
\hline \multirow{2}{*}{$\begin{array}{c}\text { Days of } \\
\text { treatments }\end{array}$} & \multicolumn{2}{|c|}{ Average No. insects (10 sweeps / plot ) } & \multirow{2}{*}{ \% Reduction } \\
\cline { 2 - 3 } & Untreated control & Malatox $57 \%$ & \\
\hline 0 & 70.00 & 22.67 & 0.00 \\
\hline 1 & 48.33 & 27.33 & 75.45 \\
\hline 2 & 42.00 & 25.67 & 88.71 \\
\hline 3 & 51.00 & 25.67 & 54.81 \\
\hline 4 & 53.33 & 23.67 & 35.72 \\
\hline 5 & 67.67 & 27.33 & 25.11 \\
\hline 6 & 61.33 & 23.67 & 18.56 \\
\hline 7 & 58.67 & 21.67 & 14.24 \\
\hline 8 & 59.33 & 20.67 & 7.38 \\
\hline 9 & 59.33 & 20.67 & 7.38 \\
\hline 10 & 60.67 & 20.67 & 4.99 \\
\hline
\end{tabular}

Table (2) indicates that, the initial kill of emulsifuable concentrate (EC) Malatox $57 \%$ was sufficient to reduce the field population of C. axillaris by $75.45 \%$ and $88.71 \%$ in the first and the second days after treatment, respectively. But drastic decline in its efficacy was started early in the third day of applications in which the reduction percent was 54.81, followed by sharp decreasing to the end of evaluation. This decline started by day $4^{\text {th }}$ to day $10^{\frac{\text { th }}{n}}$, the reduction percentages during this period were 35.72, 25.11, 18.56, 14.24, 7.38, 7.28 ad 4.99 after 4, 5, 6, 7, 8, 9 and 10 days, of application respectively.

Thus, Malatox by one or two days after application could be convenient for controlling Locust or Grasshoppers on the edible crops in Nile Vally and its Delta, specially it was not preferable to compete the desert locust plagues 2004 in these areas by ULV formulation. Also, this organophosphate compound stored for one year only, therefore its efficiency still in its high level $(88.71 \%)$, but an annual re-evaluation have to be done next year.

\section{Efficacy of the pyritheroid ULV formulation, Deltamethrin $1.25 \%$}

The ULV formulation, Deltamethrin $1.25 \%$ was also, evaluated against $C$. axillaris on alfalfa in Baharia Oasis during August. 2008. 
The obtained results of this evaluation were shown in table (3), in which the reduction in the field population of $C$. axillaris started to increase after the $2^{\text {nd }}$ day of application and the maximum percent $(93.70 \%)$ obtained the $5^{\text {th }}$ day . The reduction percentages were 78.58, 86.91, 85.06, 86.50, 93.70, 83.66, 81.08, 74.08, 71.44 and 61.46 after $1,2,3,4,5,6,7,8,9$ and 10 days of treatment, respectively. It was observed that, the nock down effect of this compound was enough to compate desert locust plagues in desert areas before its immigration to Nile Vally, because the oil and ULV formulation could be used safely in the desert area, but it unaccebtable for using against Locust and Grasshoppers on edible crops in the Nile Vally.

Table 3. Effects of the pyritheroid ULV formulation, Deltamethrin $1.25 \%$ on the field population of the Grasshopper, Catantopis axillaris in Baharia Oasis (August., 2008).

\begin{tabular}{|c|c|c|c|}
\hline \multirow{2}{*}{$\begin{array}{c}\text { Days of } \\
\text { treatment }\end{array}$} & \multicolumn{2}{|c|}{ Average No. insects (10 sweeps / plot $)$} & \multirow{2}{*}{ \% Reduction } \\
\cline { 2 - 3 } & Untreated control & Deltamethrin & \\
\hline 0 & 30.00 & 29.33 & 0.00 \\
\hline 1 & 29.33 & 6.30 & 78.58 \\
\hline 2 & 39.33 & 5.00 & 86.91 \\
\hline 3 & 36.00 & 5.33 & 85.06 \\
\hline 4 & 33.3 & 4.33 & 86.50 \\
\hline 5 & 27.33 & 2.00 & 93.70 \\
\hline 6 & 35.00 & 5.67 & 83.66 \\
\hline 7 & 35.33 & 6.33 & 81.08 \\
\hline 8 & 31.33 & 8.00 & 74.08 \\
\hline 9 & 35.67 & 10.00 & 71.44 \\
\hline 10 & 32.00 & 12.00 & 61.46 \\
\hline
\end{tabular}

\section{Efficacy of the micoinsecticide Green Muscles}

The oil formulation of Green Muscle (Metarhizium flavoviride spores) was sprayed by ULV sprayer in natural oil against Catantopis axillaris on alfalfa in Baharia Oasis in August, 2008. Due to the high temperature and the low soil humidity in the treated plots, the application was before sunset with one more irrigation to make the field conditions more suitable for the germination of the Green Muscles spores on the target insects. 
Table 4. Efficiency of the oil formulation of Metarhizum flavoviride spores, Green Muscles against the field population of the Grasshopper, Catantopis axillaris on alfalfa in Baharia Oasis (August, 2008)

\begin{tabular}{|c|c|c|c|}
\hline \multirow{2}{*}{ Days of treatment } & \multicolumn{2}{|c|}{ Average No. insects (10 sweeps / plot ) } & \multirow{2}{*}{ \% Reduction } \\
\cline { 2 - 3 } & Untreated control & Green Muscles & \\
\hline 0 & 30.00 & 28.67 & 0.00 \\
\hline 1 & 32.00 & 27.22 & 1.10 \\
\hline 2 & 61.33 & 59.00 & 9.60 \\
\hline 3 & 55.00 & 47.00 & 9.80 \\
\hline 4 & 39.00 & 42.66 & 12.42 \\
\hline 5 & 38.33 & 26.33 & 28.24 \\
\hline 6 & 34.33 & 22.00 & 33.01 \\
\hline 7 & 36.33 & 14.33 & 58.58 \\
\hline 8 & 35.33 & 10.67 & 68.55 \\
\hline 9 & 38.67 & 9.33 & 74.26 \\
\hline 10 & 40.33 & 11.00 & 71.88 \\
\hline
\end{tabular}

Table (4) indicated that, the reduction in the population of the treated $C$. axillaris started with low percentages during the first 6 days of treatment, and tended again to increase with the beginning of the $7^{\text {th }}$ day of treatment to the last day of experiment. These percentages were 58.58, 68.55, 74.26 and 71.88 in days $7,8,9$ and 10, respectively. These results reflect the slow acting of the micoinsecticide, Green Muscles against this Grasshopper inspite of its application during sunset and the high humidity in the soil of the treated plots. 

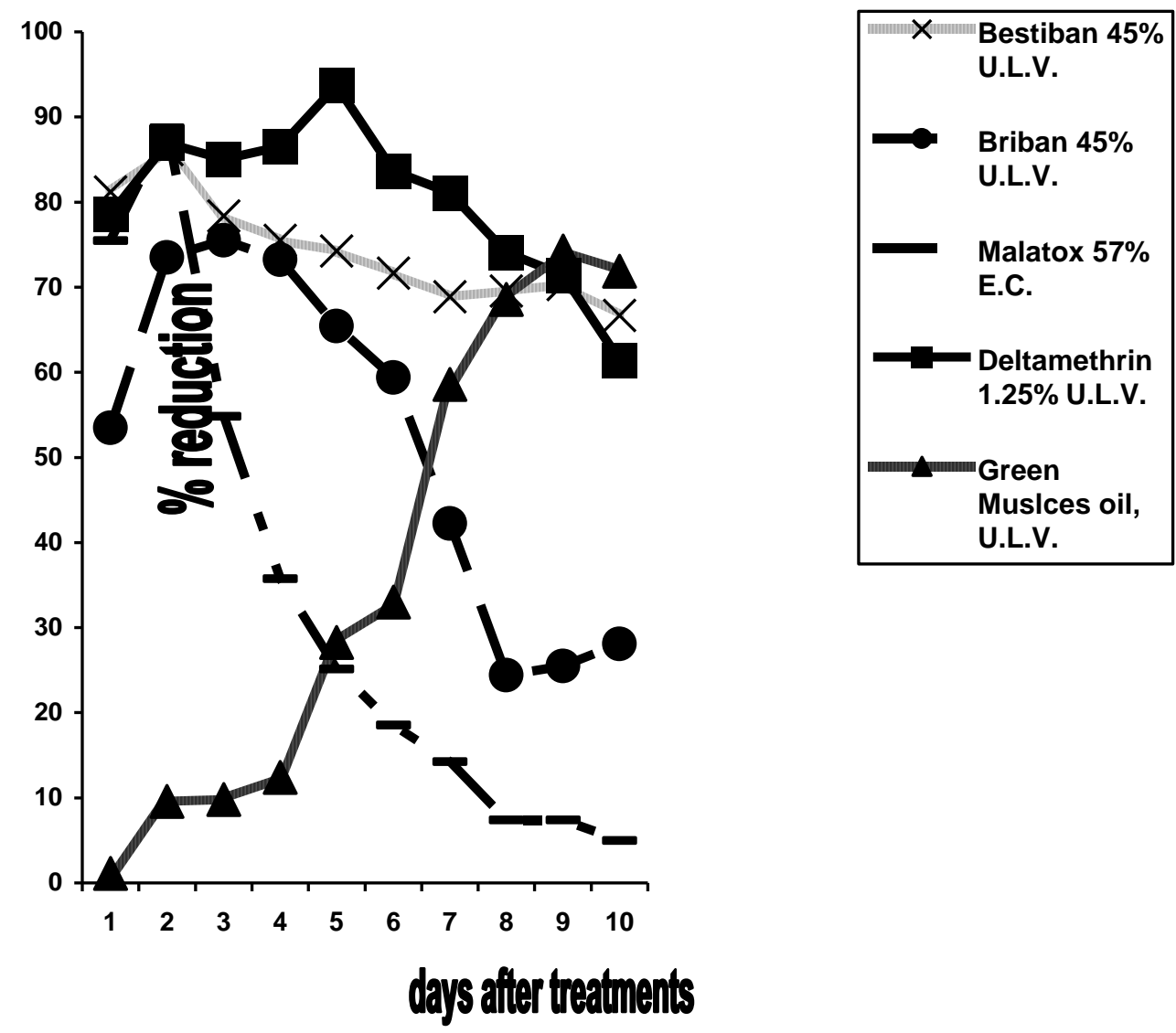

Fig .1. comparison between the reduction capacity of all the applied stored compounds against the field strain of the Grasshopper, Catantopis axillaris .

Fig : (1) and tables (1-4) showed that, the ULV formulation, Deltamethrin and Bestiban were the most effective insecticides against the Grasshoppers, C. axillaris under field conditions, followed by the moderate effect of Briban. The emulsifuable concentrate formulation of Malathion, Malatox 57\% exhibited high efficacy during the first 3 days of the application. The micoinsecticide, Green Muscles lasted 7 days to induce its lethal effect against this grasshopper. The rate of initial kill of Bestiban, Briban, Malatox, Deltamethrin and Green Muslces were 81.19, 53.47, 75.45, 78.58 and 1.10 respectively percent after application with one day. The effects of the first 4 compounds were increased in the second day, their reduction percentages ranges, between $73.48, \& 88.71$ and 86.91 . But the maximum efficacy of the micoinsecticide, Green Muscles induced after 9 days of its application.

In conclusion, the results of the present re-evaluation refer to the high performance of the stored Deltamethrim, and Bestiban ULV formulations against the target Grasshopper, C. axillaris, and the moderate effects of the other ULV formulation, Briban on this pest. On the other hand, the EC. Formulation, Malatox 
exhibited good performance only, during the first 3 days after application, wherease the micoinsecticide Green Muscles induced convenient reduction as abioinsecticide in the population of the treated Grasshopper after 9 days of treatment. These results go in line with many others field studies such as the medium-scale experimental field trials of Peveling et al. (1999) in Niger using the mycoinsecticide M. anisopliae and one of the organophosphorous compounds, Fenitrothion against Oedaleus senegalensis, the efficiency of Fenitrothion ranged from 75 to $86 \%$ over 31 day post treatment where as $M$. anisopliae had an efficiency of $76 \%$ during the last sampling period, days 21-31. They concluded that $M$. anisopliae can be effective as organophosphate Fenitrothion without threating non-target arthropods other than orthopterans. In another trial in Niger, Langwald et al. (1999) stated that the treatment with the oil formulation of $M$. anisopliae reduced the population of the treated Grasshopper significantly after 7 days and by $93 \%$ within 16 days. Fenitrothion caused a population reduction of more than $90 \%$ shortly after application. These field trials in Niger supported the results of the present study, in which we could concluded and recommended that the fast degradable EC formulation of the organophosphorous insecticides have to be used against the unusual invasions of the desert locust to Nile vally such as in 2004-2005 plague to avoied pollution and contamination. The tested ULV insecticides formulations in the present study could be used against hopper bands or adult swarms in the desert areas, except the micoinsecticide, Green Muscles which will be effective against the low density of hopper bands or Grasshopper. Also, the Chlorpyrifos formulation (Briban) have to be renewed due to its low toxicity during this bioassay.

\section{REFERENCES}

1. Cressman, K. and H.M. Dobson. 2001. Desert locust guidelines appendixes, appendix 3.1, FAO, Rome, 2001.

2. El-Gammal, A.M., M. T. Mohamed and H.A. El-Gawhary. 2002. Experimental evidence for the suppressive effect of ethanol egg pod extracts of Schistocerca gregaria (Forsk.) on their reproductive potential. $2^{\text {nd }}$ International Conference, Plant Protection Res. Institute, Cairo, Egypt.

3. El-Gammal, A.M., H.M. El-Gawhary, T.A. Abdel-Fattah and M.T. Mohamed. 2004a. Field trials to investigate the spores of Metarhizium flavoviride as microbial control agent and its integrated action with some insect growth-regulators against Locusta migratoria migratorioides in Shark El-Uwainat area. Egypt J. Appl. Sci. 19(6): 255265. 
4. El-Gammal, A.M., T.A. Abdel-Fattah, M.T. Mohamed and H.M. El-Gawhary. 2004-b. The anti-Juvenile hormone action of cycloheximide (RNA and protein synthesis inhibitor) in some nymphal instars of Schistocerca gregaria (Forskal). Egypt J. Agric. Res. 82: 1561-1571.

5. El-Gammal, A.M., A and M.T. Mohamed. 2008. Performance of two spinosyn products to compete the Grasshopper, Catantopis axillaris Thumburge, in comparison to a conventional insecticide in Baharia Oasis of Egypt. Egyptian J. Biological Pest Control., 18 (1).

6. El-Gawhary, H.M., M.T. Mohamed, A.M. Gehan and A.M. El-Gammal. 2006. The anti-moulting agent, chlorfluazaron (IKI) as an alternative control measures against the immature stages of Schistocerca gregaria (Forskal). Egypt J. Appl., Sic., 21 (4B): 627-636.

7. FAO, Desert Locust Guideline Appendixes. 2001. Locust pesticide doses rates, $8^{\text {th }}$ meeting of pesticide Refree Group (1999). Desert locust Guidelines: Appendix, 3.1: 78-79.

8. Henderson, C. and E.W. Tilton. 1955. Test with acaricides against the brown wheat mite. J. Can. Entomol., 46: 151-160.

9. Langewald, J., Z. Quambama, A. Mamadou, R. Peveling, I. Stolz, R. Bateman, S. Attignon, S. Blanford, S. Arthurs and C. Lomer. 1999. Comparison of an organophosphate insecticide with a micoinsecticide for the control of Oedaleus senegalensis (Orthoptera: Acrididae) and other Sahelian Grasshoppers at an operational scale. Biocontrol Science and Technology, 9(2): 199-214, BP08-0932 Cotonou, Benin.

10. Mohamed, T. M. 2007. Efficiency of the mycoinsecticide, Green Muscles against the Grasshoppers, Catantops axillaris Thimberg (Orthoptera: Acrididae) in Baharia Oasis. Egypt. J. of Appl. Sci. 22 (12A): 268-275

11. Peveling, R., S. Attignon, J. Langewald and Z. Duambama. 1999. An assessment of the impact of biological and chemical Grasshopper control agents on grounddwelling arthropods in Niger, based on presence/ absence sampling. Group protection, 18(5): 323-339, Institute for Environmental Sciences, Nill Biogeography, Univ. Basle, Switzerland. 


\title{
فاعلية مبيدات الجراد والنطاط المخزنة بمصر على النطاط "كاتانتويس أكسلارس" (مستقيمات الأجنحة: جراديات) تحت الظروف الحقلية بالواحات البحرية
}

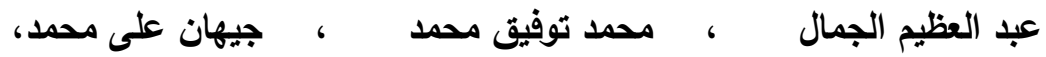 \\ محمد عبد العزيز هندى ، وممدوح عبد الحميد إبراهيم

$$
\text { بمعهد بحوث وقاية النباتات - مركز البحوث الزراعية - دقى - جيزه }
$$

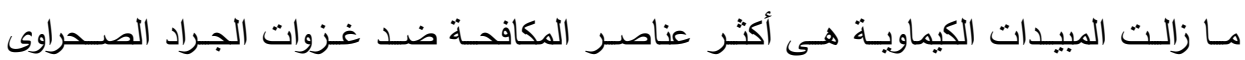

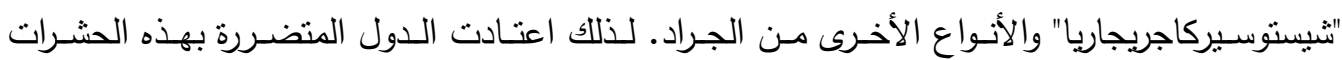

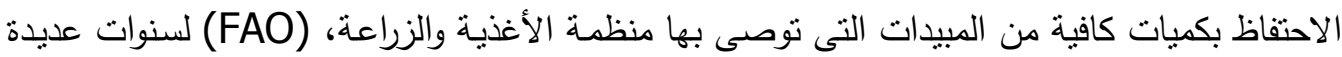

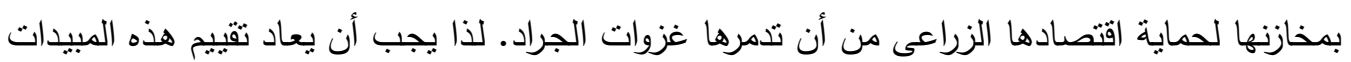

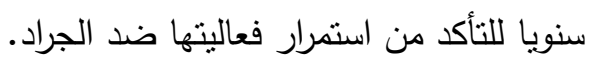

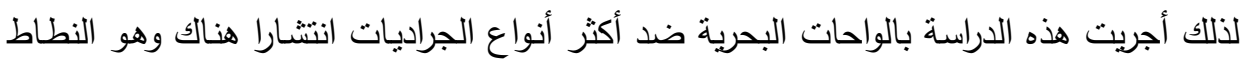

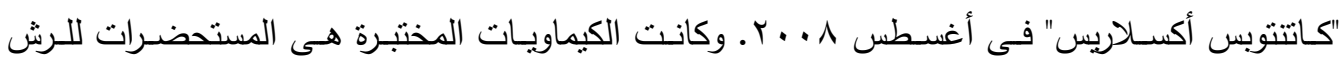

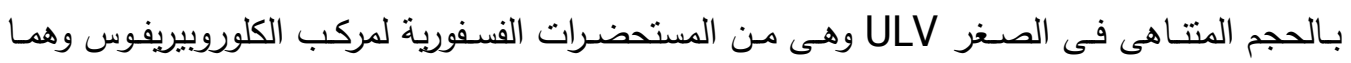

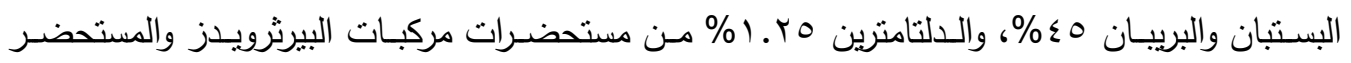

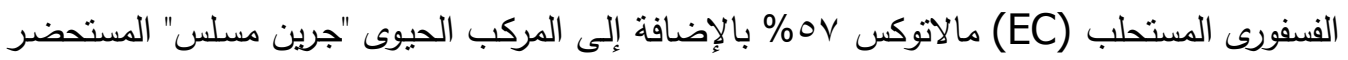
من جراثيم فطر "الميتاريزيم فلاقوفيريدى".

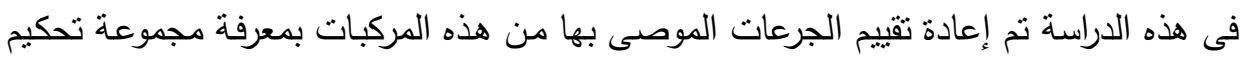

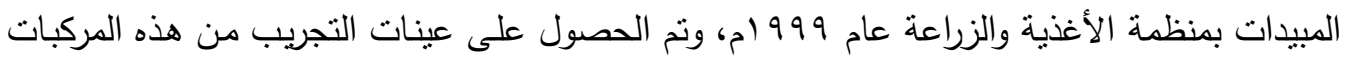

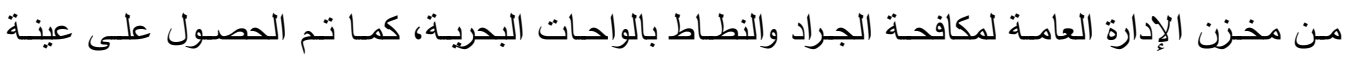

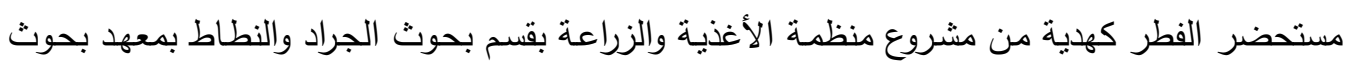

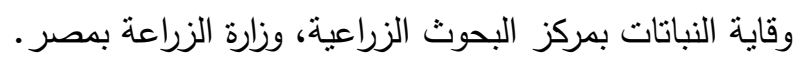

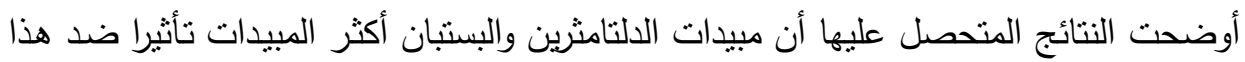

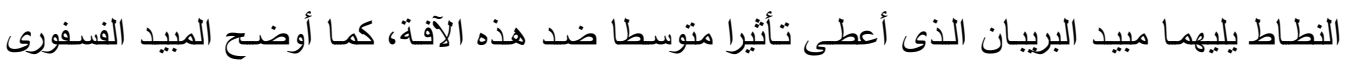

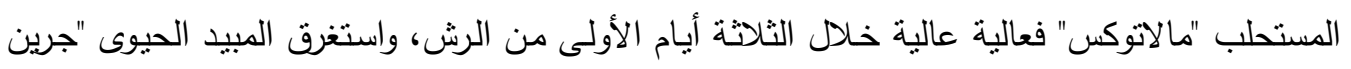

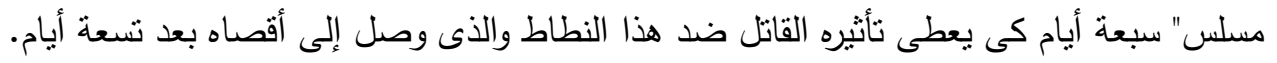

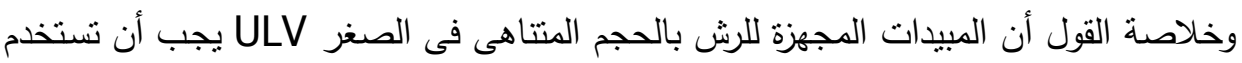

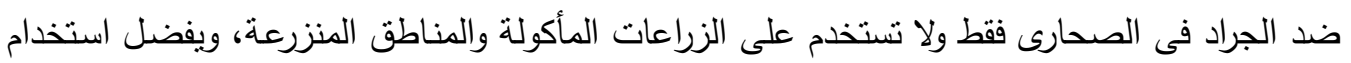
المركبات الفسفورية المستحلبة (EC) ضد الجراد والنطاط في المئ المناطق المنزرعة. كما يمكن استخدام

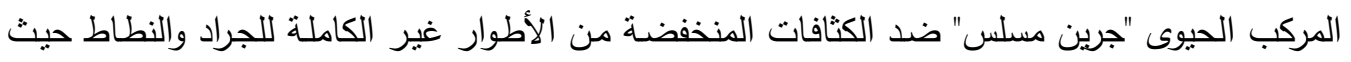

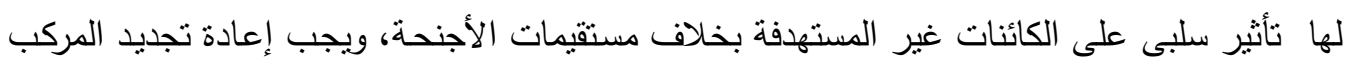

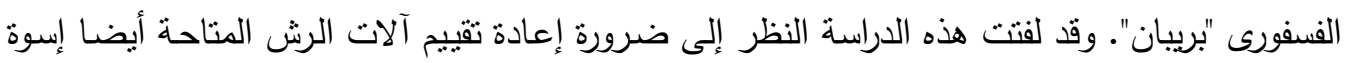
بإعادة تقييم المبيدات الخاصة بمكافحة الجراد والنطاط. 